(C2003 Marcel Dekker, Inc. All rights reserved. This material may not be used or reproduced in any form without the express written permission of Marcel Dekker, Inc.

SUBSTANCE USE \& MISUSE

Vol. 38, No. 14, pp. 2097-2107, 2003

RESEARCH NOTE

\title{
Clinician Attributions and Disease Model Perspectives of Mentally Ill, Chemically Addicted Patients: A Preliminary Investigation
}

\author{
Jacqueline D. Kloss ${ }^{1, *}$ and Stephen A. Lisman, Ph.D. ${ }^{2}$ \\ ${ }^{1}$ Department of Psychology, Drexel University, \\ Philadelphia, Pennsylvania, USA \\ ${ }^{2}$ State University of New York at Binghamton, \\ Binghamton, New York, USA
}

\begin{abstract}
Brickman et al.'s (Brickman, P., Rabinowitz, V. C., Coates, D., Cohn, E., Kidder, L. (1982). Models of helping and coping. American Psychologist 37:364-384.) models of helping and coping provided a framework by which to compare clinicians' attributions of blame and control among several hypothetical patients. Sixty-one mental health clinicians (MHCs) and addiction clinicians (ACs) - mostly master's level clinicians and registered nurses - rated attributions toward vignettes that depicted individuals with schizophrenia, alcoholism,
\end{abstract}

*Correspondence: Jacqueline D. Kloss, Department of Psychology, Drexel University, 3141 Chestnut St., Philadelphia, PA 19104, USA; E-mail: jdk29@, drexel.edu.

DOI: $10.1081 /$ JA-120025127

Copyright (c) 2003 by Marcel Dekker, Inc.
1082-6084 (Print); 1532-2491 (Online) www.dekker.com 
and mentally ill, chemically addicted (MICA) classifications in 1995. Results indicate that MHCs attributed more blame to MICA patients than did ACs, but did not differ on their attributions of control. MHCs' and ACs' attributions of blame and control were generally low, consistent with a medical model. However, the endorsement of a disease model of alcoholism did not significantly predict the amount of blame attributed by the clinicians. Implications for treatment planning for MICA patients are discussed.

Key Words: Blame; Dual diagnosis; Clinician attributions; Responsibility; MICA (mentally ill chemically addicted).

The clinical presentation of mentally ill, chemically addicted (MICA) patients poses a significant challenge for clinicians (Carey, 1992). The concurrent manifestation of symptoms from both chemical addiction and mental illness makes the diagnosis, conceptualization, and subsequent treatment decision-making elusive, and often results in poor treatment response and outcome (Mueser, et al., 1992). When MICA patients appear at agencies that primarily treat addictions, they are most likely to be viewed within a disease model, because this perspective tends to predominate among alcoholism-treatment providers and institutions in the United States (e.g., Humphreys et al., 1995). Conversely, it is in a mental health setting where patients with psychoses are treated, and where the focus is often medical or pharmacological. Clinicians' adherence to either of these unidimensional frameworks may be potentially countertherapeutic for the treatment of MICA patients. Likewise, enrolling the patient in two separate agencies may be counterproductive. For example, although Alcoholics Anonymous(AA) does not "officially" ostracize individuals who use prescribed medication, those sentiments may still exist (Osher and Kofoed, 1989; Zweben, 1993).

Brickman et al. (1982) offer several models that can describe how mental health clinicians (MHCs) conceptualize case presentations, based on how they attribute blame (responsibility for the cause of a problem) and control (responsibility for coping with or solving a problem). Their approach is particularly well-suited to understand the confusion that might be posed when confronting the concurrent manifestation of addiction and mental illness. For example, Table 1 illustrates how one might apply Brickman et al.'s (1982) models to conceptualize alcoholism. Thus, the orientation of addiction clinicians (ACs) to alcoholism might best be described by a medical model or by a compensatory model. Given the complexity of the clinical presentation of MICA patients, we 
predicted that clinicians from both addiction and mental health settings would attribute minimal responsibility to MICA patients for causing their problem (blame), but would differ with respect to their expectations for problem resolution (control).

\section{METHOD}

\section{Materials}

We constructed a questionnaire comprising six vignettes, two depicting individuals with a DSM III-R diagnosis of Psychoactive Substance Dependence (Alcohol), two depicting a diagnosis of Schizophrenia, and two depicting individuals characterized by a combination of these diagnoses (MICA). We chose schizophrenia as the mental health comparison diagnosis because we believed it to be the least ambiguous to conceptualize on dimensions of blame and control, and therefore most likely to illuminate differences in MICA conceptualizations between providers.

Each vignette was followed by the same six questions (three measuring blame and three measuring control, see Table 2). We also assessed clinicians' endorsement of a disease model of alcoholism using 21 items from a portion of Moyers and Miller 's (1993) Understanding of Alcoholism Scale, for which they reported good reliability. Although questions were asked about three types of disorders, in this report we focus primarily on the results for MICA patients.

\section{Procedure}

The investigator negotiated with several local agency directors who identified their settings as serving primarily or exclusively mentally ill or addicted patients in order to find the optimal means to administer the questionnaire. In accordance with agency requests, the investigator either met with staff and gave a brief overview of the project without revealing the hypotheses, or had the agency administrator distribute the questionnaire to his or her staff. All clinicians were also given a stamped envelope and requested to return the questionnaire to the investigator, to whom the envelope was addressed. Of the 156 questionnaires distributed, $40 \%$ were returned. Our final sample consisted of 61 clinicians $(70 \%$ women) whose primary place of employment was at either an alcohol-user treatment center $(N=32)$ or a community mental health center $(N=29)$; see Table 3 for descriptive characteristics. 
Table 2. Sample vignette with blame and control rating scales.

Andrew's presentation at the clinic focused on his inability to stop drinking without suffering withdrawal symptoms, e.g., headaches, stomach aches, and nausea. He complained that he was not feeling like he used to. He was having difficulty going to work and was having problems at home. He reports that at times, it is difficult for him to get out of bed in the morning. He reports having to drink twice as much as he used to just to feel "normal." After a thorough evaluation, Andrew was diagnosed with Psychoactive Substance Dependence (Alcohol).

On a scale of $1-10(1=$ not at all and $10=$ very much $)$, please rate the following: To what extent do you feel that Andrew (a) is responsible for his problems; (b) could have avoided the problems that he has; (c) could have controlled the cause of his problems; (d) is personally responsible for creating a solution; (e) can overcome his problems by himself; and (f) can control the solution to his problems.

Note: The coefficient alphas derived for the alcoholism, schizophrenia, and MICA blame scales were $0.90(n=54), 0.89(n=57)$, and $0.93(n=55)$, respectively. Likewise the coefficient alphas derived for alcoholism, schizophrenia, and MICA control scales, were $0.63(n=54), 0.81(n=57)$, and $0.78(n=55)$, respectively. Our decision to select only men for the vignettes was due to the practical limits imposed by the demands of this study on the volunteering clinicians.

Table 3. Participant characteristics.

\begin{tabular}{lrr}
\hline & MHCs & ACs \\
\hline $\begin{array}{l}\text { Number of participants } \\
\text { Gender }\end{array}$ & 32 & 29 \\
$\quad$ Women & 22 & 21 \\
$\quad$ Men & 8 & 8 \\
Mean age & 44 & 43 \\
Years affiliated with agency & 9 & 7 \\
Education & & \\
$\quad$ High school & 2 & 5 \\
Some college & 1 & 3 \\
BA/BS & 2 & 10 \\
MA/MS & 16 & 9 \\
RN & 5 & 2 \\
Other & 6 & 9 \\
Certified addiction counselors & 1 & 5 \\
Identified self as "recovering" & 1 & \\
Identified self as having a mental illness & 4 & \\
\hline
\end{tabular}

a2 participants did not identify gender. 


\section{RESULTS}

\section{Attributions of Responsibility: Blame and Control}

Our results do not support the hypothesis that ACs would differ from MHCs in the amount of control attributed to MICA patients. Instead, clinicians were differentiated by their attributions of blame. The threeway interaction (Control $\times$ Type of Agency $\times$ Diagnosis) was significant, $F(2,100)=4.25, p=0.05$, but follow-up analysis of variance (ANOVA) indicated that the type of agency where a clinician worked did not differentiate the amount of control attributed in response to the MICA vignettes, nor to the alcoholic and schizophrenic vignettes (all $p$ 's $>0.05$ ). In contrast, with regard to the MICA depiction, MHCs rated significantly higher attributions of blame $(M=3.65, S D=1.09)$ than did the ACs $(M=2.05, \mathrm{SD}=1.24), t(1,54) 13.74, p<0.01$.

Including both agencies, examination of all subjects' scores on the Understanding Alcoholism Scale revealed moderate-to-high endorsement of a disease model $(M=73, \mathrm{SD}=12$, range $=21-105)$. Of the 59 respondents to the scale, $78 \%$ of the participants scored in the upper half of the scale (above 64, range $=22-105$ ). Disease ratings did not correlate with blame ratings, $r(51)=-0.19, p>0.05$.

\section{Descriptive Predictors of Blame and Control}

We examined whether descriptive information would correlate with aspects of blame and control. Interestingly, the amount of blame attributed to an alcoholic was significantly less as a function of the following characteristics of treatment providers: Recovering Alcoholics $(M=14.2$, $n=10)$ vs. Individuals Not in Recovery $(M=24.07, n=44), F(1,53)=$ $5.102, p=0.03$; CACs $(M=13.2, n=15)$ vs. NON CACs $(M=25.72$, $n=39), F(1,53)=12.29, p=0.001$, and those who refer patients to AA $(M=18.71, n=42)$ vs. those who do not $(M=34.58, n=12), F(1,53)$, $18.718, p<0.000$. However, these same variables did not differentiate relative endorsement of a disease model of alcoholism, all $p$ 's $>0.05$.

\section{DISCUSSION}

Our efforts to examine Brickman et al.'s (1982) models led to several interesting findings. Although both blame and control scores were low overall, MHCs clearly attributed more blame (causal responsibility) to 
MICA patients than did ACs. Nevertheless, MHCs and ACs offered somewhat equivalent ratings when they were attributing responsibility for solving one's problems. These findings were opposite of the predictions based on our interpretation of Brickman et al. (1982) that both groups of clinicians would reveal similar attributions of blame and differ in their attributions of control. An examination of several explanations for these findings follows.

The descriptive information collected from clinicians, such as identification as a Certified Addiction Counselor (CAC), whether or not one refers patients to AA, and whether or not one is personally "in recovery," comprised characteristics that reflected lower attributions of blame. These characteristics were more representative of addiction clinicians and may account for the lower attributions of blame. Jones and Nisbett's (1971) theory of the fundamental attribution error asserts that when actors make attributions about something that happens to them, they are likely to attribute the cause to the external situation. However, observers are more likely to make an internal attribution and attribute the cause to some aspect of the individual, rather than to the situation. Since many of the ACs indicated that they are "in recovery" themselves (thereby "actors"), perhaps they were less likely to blame or attribute having a disorder to an internal cause, but rather to an external or situational determinant. Consequently, they may have reduced their blame of an individual for having a problem.

Despite MHCs' and ACs' similarly high disease-model endorsements, their scores on this questionnaire did not predict blame ratings. Although one of the historical roles of the disease model was to lessen the moral and accusatory perspective by which alcoholics were viewed, Blum et al. (1989) demonstrated that disease model endorsement does not necessarily reflect attributions of decreased blame. Moreover, our prediction that adherents to AA and disease models would emphasize the attribution of responsibility for solving one's own problems (control) was not supported. As McCrady (1994) suggests, AA de-emphasizes personal control in the domain of treatment. Perhaps the widespread acceptance of AA lessens perceptions of control among clinicians by encouraging their over-reliance on patients surrendering their control to a "Higher Power." It may be this idea that is captured by clinicians" low-to-moderate ratings of control attributed to their patients.

\section{Limitations}

For the purposes of this study, we chose a convenience sample of clinicians and limited our vignettes to MICA patients with dual diagnoses 
of alcoholism and schizophrenia. It would also be interesting to examine patients' attributions of their own blame and control as well as those of their treating clinicians. For example, Mechanic et al. (1994) suggest that patients with conditions such as schizophrenia, tend to feel stigmatized by their disorder when they conceptualize it as a physical illness. And several studies of alcohol treatment providers (Cunningham et al., 1996; Forman et al., 2001; Thombs and Osborn, 2001) reveal quite varied "typologies" and orientations that appear linked in diverse ways to ideas about treatment and recovery. Indeed, Schaler (1995) suggests matching patients and therapists according to their beliefs about clinical problems. Perhaps conflicting attributions between therapists and their patients on measures of blame and control may contribute to conflicts in compliance with treatment plans. Answers to such questions may help us begin to understand how attributions of blame and control translate into practice... surely the endeavor most critical to the welfare of all patients.

\section{ACKNOWLEDGMENTS}

The authors appreciate the contributions of Thomas H. Brandon and Jane M. Connor. The authors also acknowledge the generosity of the participating clinicians for their time and effort in completing the questionnaires.

\section{REFERENCES}

Blum, T., Roman, P. M., Bennett, N. (1989). Public images of alcoholism: data from a Georgia survey. Journal of Studies on Alcohol 50:5-14.

Brickman, P., Rabinowitz, V. C., Coates, D., Cohn, E., Kidder, L. (1982). Models of helping and coping. American Psychologist 37:364-384.

Carey, K. (1991). Research with dual diagnosis patients: challenges and recommendations. The Behavior Therapist 14:5-8.

Cunningham, J., Sobell, L., Sobell, M. B. (1996). Are disease and other conceptions of alcohol abuse related to beliefs about outcome and recovery? Journal of Applied Social Psychology 28:773-780.

Forman, R. F., Bovasso, G., Woody, G. (2001). Staff beliefs about addiction treatment. Journal of Substance Abuse Treatment 21:1-9. 
Humphreys, K., Greenbaum, M. A., Noke, J., Finney, J. (1995). Reliability, validity, and normative data for a short version of the understanding of alcoholism scale, Psychology of Addictive Behaviors 10:38-44.

Jones, E. E., Nisbett, R. E. (1971). The Actor and the Observer: Divergent Perceptions of the Cases of Behavior. Morristown, NJ: General Learning Press.

McCrady, B. (1994). Alcoholics anonymous and behavior therapy: Can habits be treated as diseases? Can diseases be treated as habits? Journal of Consulting and Clinical Psychology 62:1159-1166.

Mechanic, D., McAlpine, D., Rosenfield, S., Davis, D. (1994). Effects of illness attribution and depression on the quality of life among persons with serious mental illness. Social Science Medicine 39:155-164.

Milam, J. R., Ketcham, K. (1983). Under The Influence: A Guide To Myths And Realities Of Alcoholism. New York: Bantam Books.

Moyers, T. B., Miller, W. R. (1993). Therapist conceptualizations of alcoholism: measurement and implications for treatment decisions. Psychology of Addictive Behaviors 7:238-245.

Mueser, K., Bellack, A., Blanchard, J. (1992). Comorbidity of schizophrenia and substance abuse: Implications for treatment. Journal of Consulting and Clinical Psychology 60:845-856.

Osher, F., Kofoed, L. (1989). Treatment of patients with psychiatric and psychoactive substance abuse disorder. Hospital and Community Psychiatry 40:1025-1030.

Schaler, J. A. (1995). The addiction belief scale. International Journal of the Addictions 30:117-134.

Thombs, D. L., Osborn, C. J. (2001). A cluster analytic study of clinical orientations among chemical dependency counselors. Journal of Counseling and Development 79:450-448.

Zweben, J. (1993). Dual diagnosis: key issues for the 1990's. Psychology of Addictive Behaviors 7:163-172.

\section{RESUMEN}

Los modelos de ayuda y 'coping' de Brickman y cols. (1982) proporcionan un marco teórico desde el que se pueden comparar las atribuciones de culpa y de control de los sintomas que los profesionales clínicos hacen sobre pacientes hipotéticos. Sesenta y un profesionales clínicos de salud mental (PCSM) y profesionales clínicos de tratamiento de adicciones (PCTA), en su mayoría psicólogos clínicos con una 
Maestría y enfermeras registradas, hicieron atribuciones sobre viñetas que describen pacientes clasificados como esquizofrénicos, alcohólicos, y enformos mentales con adicciones químicas (EMAQ). Los resultados indican que los PCSM atribuyeron más culpabilidad a los pacientes clasificados como EMAQ que los PCTA, aunque estos dos grupos de profesionales no se diferenciaron en sus atribuciones de control. Las atribuciones de culpabilidad y de control fueron generalmente bajas tanto en los PCSM como en los PCTA, lo que es consistente con un modelo médico. Sin embargo, el uso de un modelo de enfermedad del alcoholismo no predijo significativamente la cantidad de culpabilidad atribuida por los profesionales clínicos. En el presente artículo, discutimos las implicaciones que estas observaciones tienen para el tratamiento de los pacientes clasificados como EMAQ.

\section{RÉSUMÉ}

Les modèles suggérés par Brickman et al. (1982) ont fourni le cadre de la présente étude. Celle-ci se présente comme une comparaison des notations d'experts appelés à évaluer la double responsabilité de malades face à l'origine de leur situations et face à la solution à leur état. Soixante et une personnes - pour la plupart diplômées en nursing ou titulaires d'une maîtrise et spécialisées dans le traitement des maladies mentales (SMM) ou des toxicomanies (ST)- ont coté les deux types de responsabilités des malades incarnés par des comédiens jouant des rôles de schizophrènes, d'alcooliques, de malades mentaux ou de toxicomanes.

Au terme de 1 étude, il appert que les SMM rejettent la responsabilité de leur maladie sur les malades plus que ne le font les ST, et que SMM et ST sont d'accord sur le degré de responsabilité des personnes atteintes quant à la prise en main de leur situation. Mais dans l'ensemble, et à l'instar de la médecine, SMM et ST cotent assez bas les deux types de responsabilité. Par ailleurs même si l'on accepte de vior l'alcoolisme comme une maladie, cela ne se traduit pas par une notation semblable à celle des autres pathologies pour ce qui de la responsabilité des malades dans la survenue de leur état.

L'étude met en lumière les conséquences de ces points de vue pour la mise au point de traitements appropriés par les malades mentaux et les toxicomanes. 
(C)2003 Marcel Dekker, Inc. All rights reserved. This material may not be used or reproduced in any form without the express written permission of Marcel Dekker, Inc.

\section{THE AUTHORS}

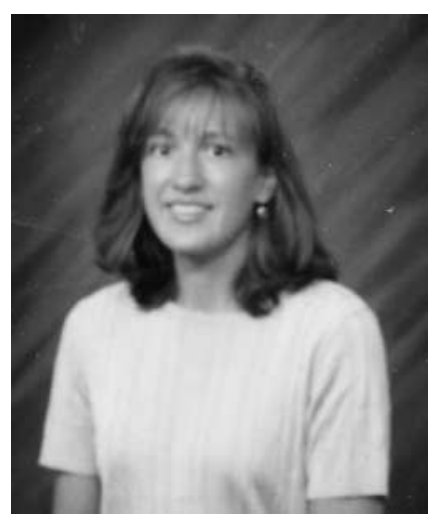

Jacqueline Kloss is an Assistant Professor in the Department of Psychology at Drexel University. She holds a postdoctoral fellowship position at the University of Pennsylvania. Her research and clinical interests are in health psychology. While she has maintained interest in addictive behaviors, her research program has evolved to include the relationship between stress and illness, as well as a specialty in behavioral sleep medicine.

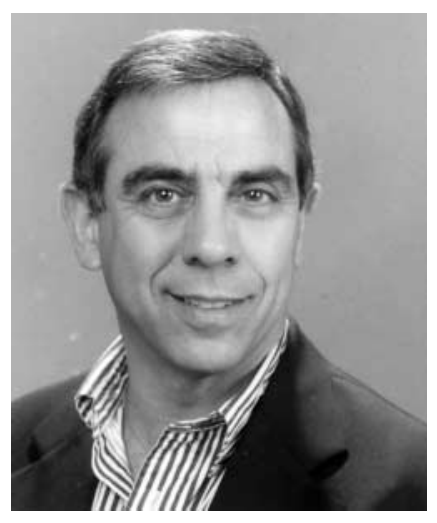

Stephen A. Lisman, Ph.D., is a professor of psychology and Director of the Psychological Clinic at Binghamton University's Department of Psychology. He directs a research program on alcohol and behavior and has published numerous scholarly articles and chapters in this area. In addition to his faculty appointment, he maintains an active practice in clinical psychology and directs the program evaluation component of a countywide, CSAP-funded adolescent alcohol and drug prevention program. 


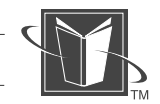

Marcel DekKer, Inc. • 270 MAdison AvenUe • New York, NY 10016

C)2003 Marcel Dekker, Inc. All rights reserved. This material may not be used or reproduced in any form without the express written permission of Marcel Dekker, Inc. 
Copyright of Substance Use \& Misuse is the property of Marcel Dekker Inc. and its content may not be copied or emailed to multiple sites or posted to a listserv without the copyright holder's express written permission. However, users may print, download, or email articles for individual use. 